\title{
Influence of the catchment area use on the water quality in the Utrata River
}

\author{
Katarzyna Dębska • Beata Rutkowska • \\ Wiesław Szulc
}

Received: 16 March 2021 / Accepted: 22 January 2022 / Published online: 10 February 2022

(C) The Author(s) 2022

\begin{abstract}
The present paper discusses the impact of land use and seasons on the concentration of nutrients in the waters of the Utrata River (Pruszków Poviat, Mazowieckie Voivodeship) from April 2018 to March 2019. The pollution of rivers by nutrients is a major problem for society. Surface water is a source of drinking water, water used for industrial and agricultural purposes. With the increasing pollution of rivers, the purification process for these purposes becomes more expensive and more challenging. To assist in carrying out activities aimed at reducing the inflow of biogenic substances into large river systems and then down to the Baltic Sea, we analyzed the spatial and temporal dynamics of loads from the entire Utrata River catchment area. We divided the entire catchment area into three impact zones: grasslands and wastelands, urbanized areas, and agricultural land and examined changes in nutrient concentrations (total phosphorus, nitrate nitrogen, ammonium nitrogen) in each of the zones. The results were statistically processed using the 1 -factor ANOVA method
\end{abstract}

K. Dębska ( ()$\cdot$ B. Rutkowska · W. Szulc Institute of Agriculture, Independent Department of Agriculture Chemistry, Warsaw, University of Life Sciences, Nowoursynowska 166, 02-787 Warsaw, Poland e-mail: katarzyna_debska@sggw.edu.pl

B. Rutkowska

e-mail: beata_rutkowska@sggw.edu.pl

W. Szulc

e-mail: wieslaw_szulc@sggw.edu.pl with the $p$-value of significance below 0.05 . Research indicates an increase in the concentration of total phosphorus and nitrogen forms down the course of the river in urban and agricultural areas with persistently low concentrations of these biogenic substances in grasslands.

Keywords Total phosphorus $\cdot$ Nitrate nitrogen · Ammonium nitrogen - River pollution · Utrata River . Biogenic substances

\section{Introduction}

The quality of the water flowing out of the catchment area of a river depends primarily on the form of land development (Fig. 1). Other factors on which water quality depends are climate, weather conditions, the presence of buffer zones, and size and location of the catchment area (Lúcia et al., 2020). The in-depth knowledge of the sources of pollution and the dynamics of its travel in the riverbed are crucial for the preservation and improvement of river water quality. The analysis of water from the entire course of the river, taking into account, for example, the uses of the catchment area (agricultural use areas, urbanized areas, and grasslands) gives us such a possibility (Fig. 2) (Schmalz \& Kruse, 2019). Biogenic pollutants in Polish rivers flow into the Baltic Sea, causing its eutrophication. Polluted rivers are responsible for 


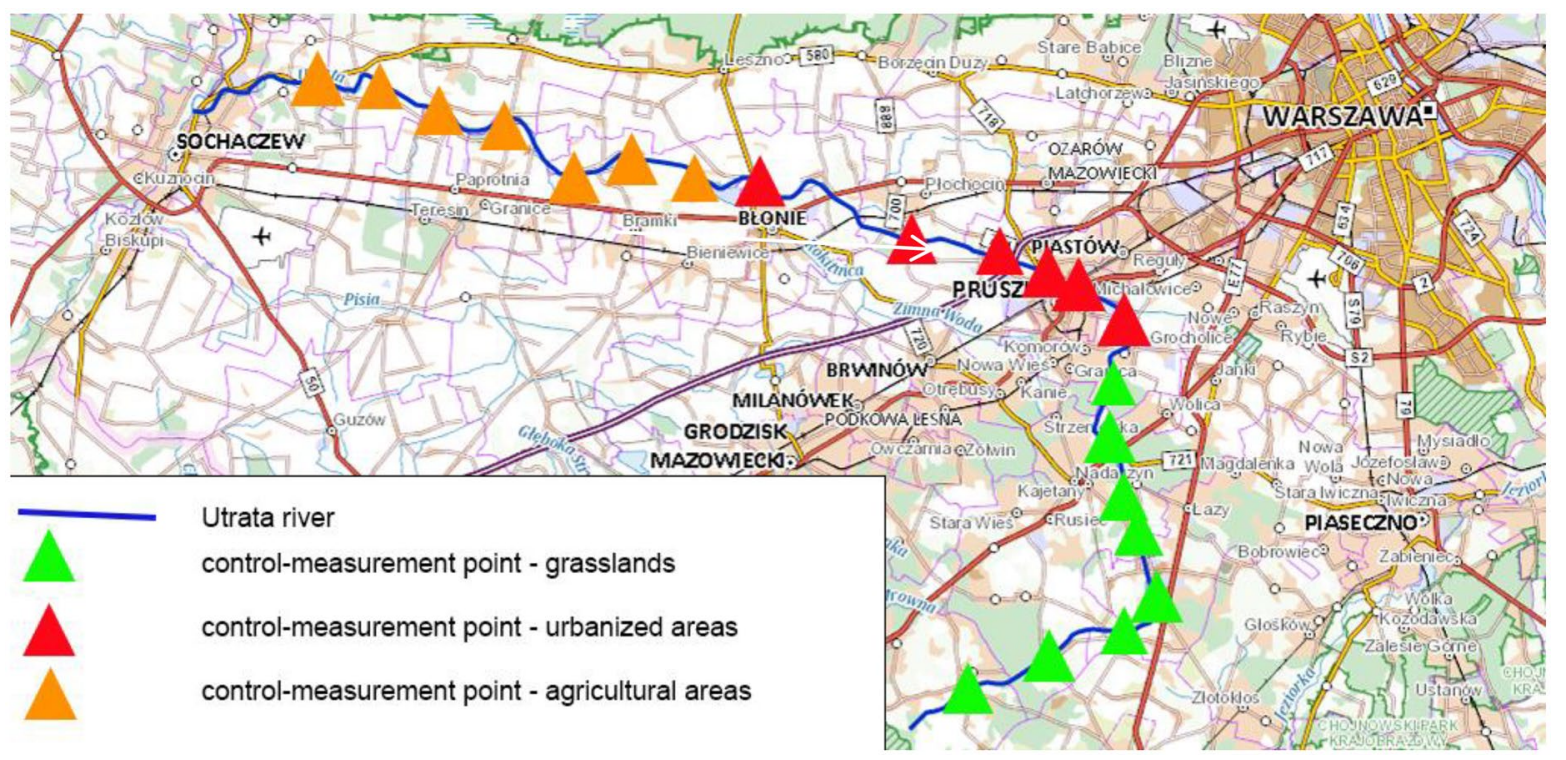

Fig. 1 Study area: location control-measurement point in the Utrata River (https://mapy.geoportal.gov.pl/imap/Imgp_2.html? gpmap=gp0; access 11 Feb 2021)

$100 \%$ of the phosphorus present in the Baltic Sea and some $20-30 \%$ of its nitrogen (Bartnicki, 2019).

Research conducted by Paule-Mercado et al. (2017), Cavalcante et al. (2017), and Rodrigues et al. (2018) demonstrates that the link between the quality of water in rivers and the type of catchment used (urbanized and agricultural land) varies, depending on the terrain, region, weather, and climatic conditions. Therefore, it proves necessary to conduct comprehensive research in various regions in order to fully understand this relationship (Baker, 2006). What was noticed in recent years is the changing dynamics of pollution in surface waters, resulting from global warming, which results in more frequent droughts and floods that lead to changes in the condition of river waters and changes in pollutant concentrations (Fig. 3) (Dzhamalov et al., 2019).

The waters in agricultural areas contain high concentrations of biogenic substances such as total phosphorus, nitrate nitrogen, and ammonium nitrogen, the sources of which are organic and mineral fertilizers (Fierro et al., 2017). High local concentrations of phosphorus may also be the result of municipal pollution (Shen et al., 2020).

An increase in nitrate nitrogen concentration may also be triggered by agriculture, especially in the lowlands, in the lower parts of the river, where organic matter is nitrified and fertilizer components are leached (Mingming et al., 2019).

Ammonium nitrogen, next to nitrate nitrogen, is another indicator of surface water pollution. The concentration of ammonium nitrogen depends on the season and climatic and atmospheric conditions and usually increases in the lower parts of the river. The main sources of ammonium nitrogen in rivers are point sources, e.g., sewage treatment plants and surface sources - surface runoffs from farmlands. However, the sources of pollution and the factors affecting its concentration in rivers may be unique to each case study (Armstrong et al., 2012). In recent years, decreasing concentrations of ammonium nitrogen in river waters have been observed, which is related to the improvement of wastewater management (Wang et al., 2016). Studies demonstrate that long-term elevated concentrations of ammonium nitrogen in rivers negatively impact microbiological life, also resulting in the possible loss of benthic diversity of invertebrates (Shi et al., 2019; Hampel et al., 2017).

The impact of climate change, summer droughts, and floods has, to the present date, been evaded in research; however, some studies demonstrated that droughts have a significant effect on temperature and dissolved oxygen content but do not affect the 
Fig. 2 Study area: land use in the Utrata River catchment area (https:// www.google.pl/maps/@52. 0917827,20.757677,10z/ data $=! 5 \mathrm{~m} 1 ! 1 \mathrm{e} 4$; access 11 Mar 2021)

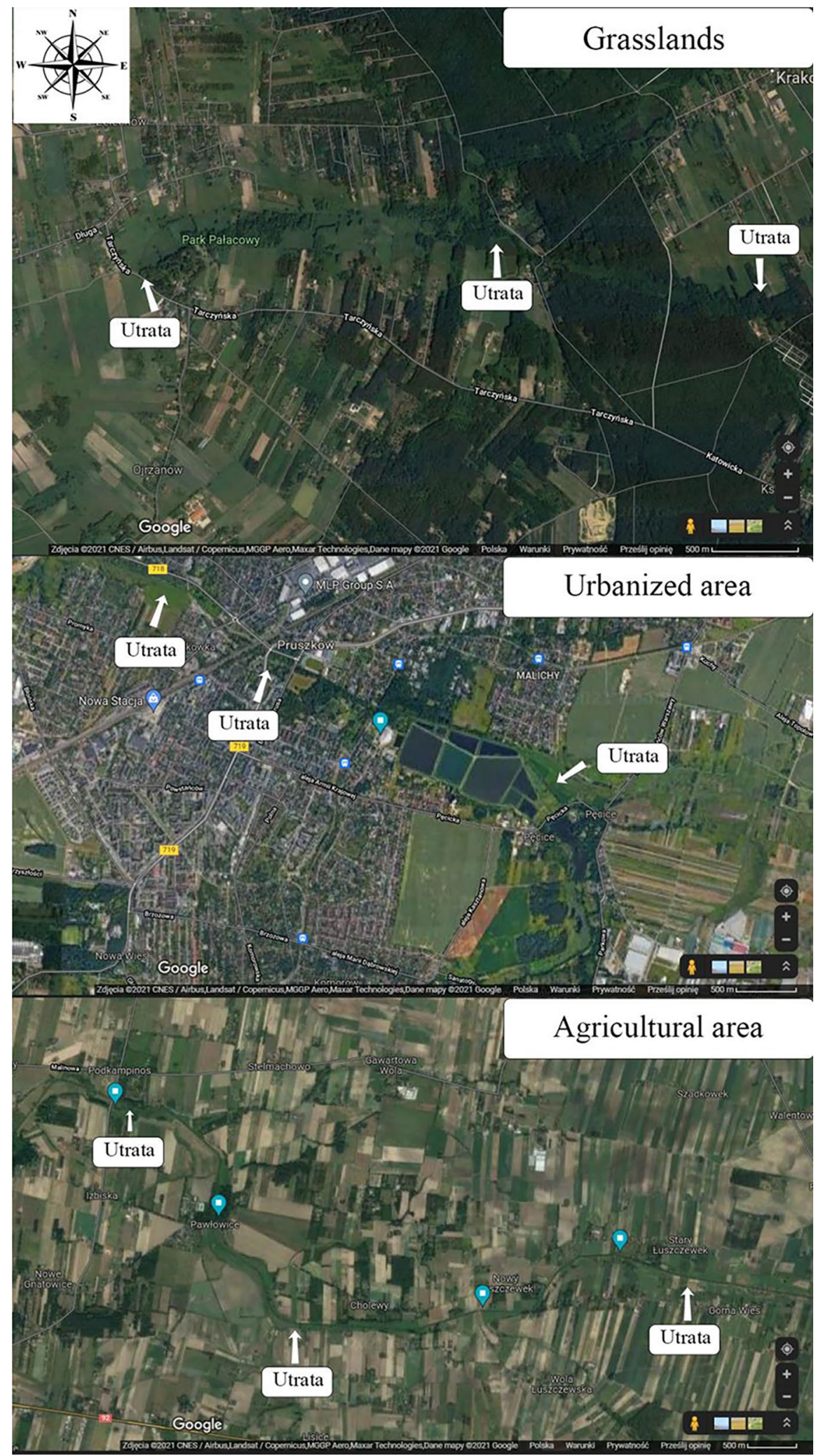


Fig. 3 Water level in the Utrata River on the measurement days ( source: https://dane.imgw.pl/data/ dane_pomiarowo_ obserwacyjne/)

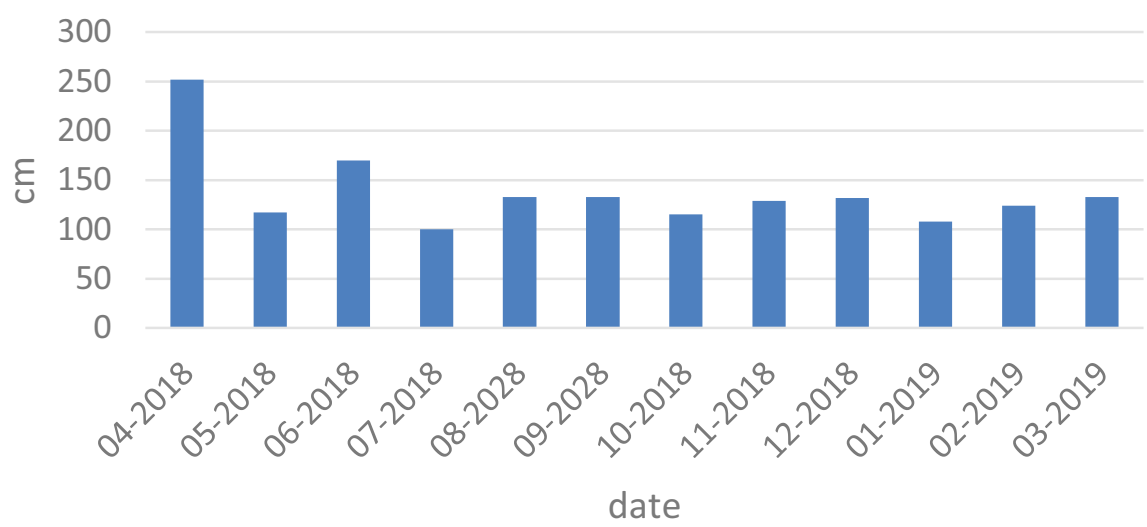

concentration of biogenic substances (Zwolsman \& van Bokhoven, 2007).

The objective of our research effort is to analyze the dynamics of pollution and identify the sources of pollution within the Utrata River catchment area.

\section{Methods}

The Utrata River is $78 \mathrm{~km}$ long and its catchment area amounts to approximately $702 \mathrm{~km}^{2}$. It flows through the Mazowieckie Voivodeship and has its source in Ojrzanów and its outlet in Sochaczew (where it becomes a tributary of the Bzura River). The exposure of the Utrata River to pollution comes from the following sources: fish ponds, sewage treatment plants, heat and power plants, landfills, and progressive urbanization (Wojtkowska, 2006). Agriculture forms a very significant source of pollution entering the river. A considerable proportion of the catchment area is covered by black earth (fertile soils), which makes agriculture in this area highly developed and specialized (Rydałowski et al., 2008).

Water samples for analyses were collected monthly from April 2018 to March 2019 at 21 sampling locations located along the entire river course (Figs. 4, 5 , and 6). The study of the river was scheduled for 1 year in order to observe the influence of the season on changes in concentrations of the nutrients. The sampling points were located in areas of different land use. The Utrata River was divided into 3 areas: grasslands from the river source to the 26th $\mathrm{km}$, urbanized areas from the 26th to the 49th $\mathrm{km}$, and agricultural areas from the $49 \mathrm{th} \mathrm{km}$ to the river outlet. The river measurements were created basing on field observations and using the QGIS software. Samples 1-8 came from grasslands, 9-14 from urbanized areas, and 15-21 from agricultural areas. Two hundred fiftytwo samples were collected.
Fig. 4 Air temperature detected on the measurement days (https://dane. imgw.pl/data/dane_ pomiarowo_obserwacyjne/)

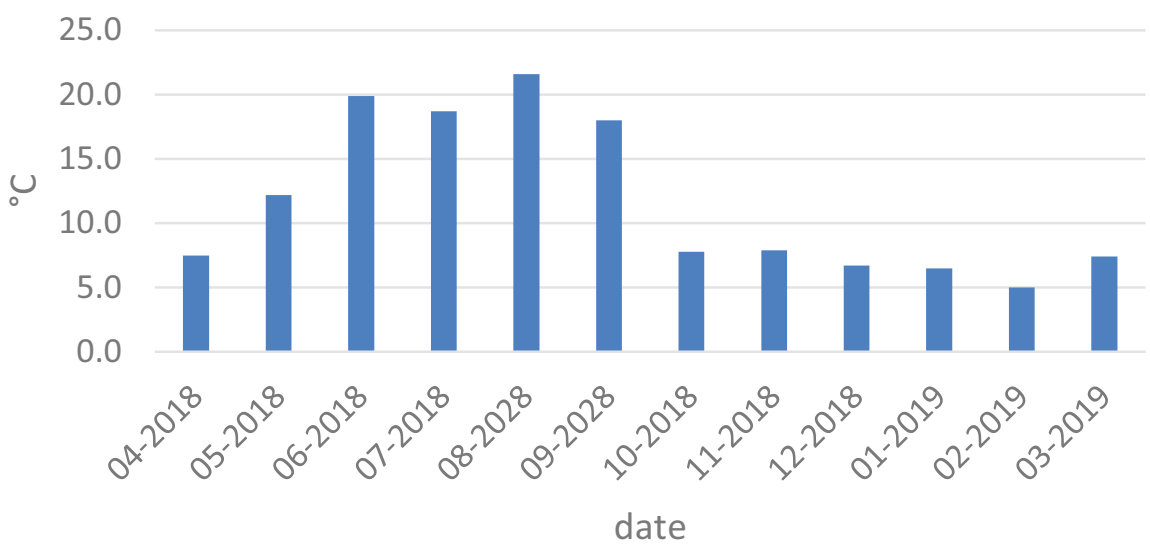


Fig. 5 Concentration of total phosphorus in the Utrata River during the months of April 2018March 2019

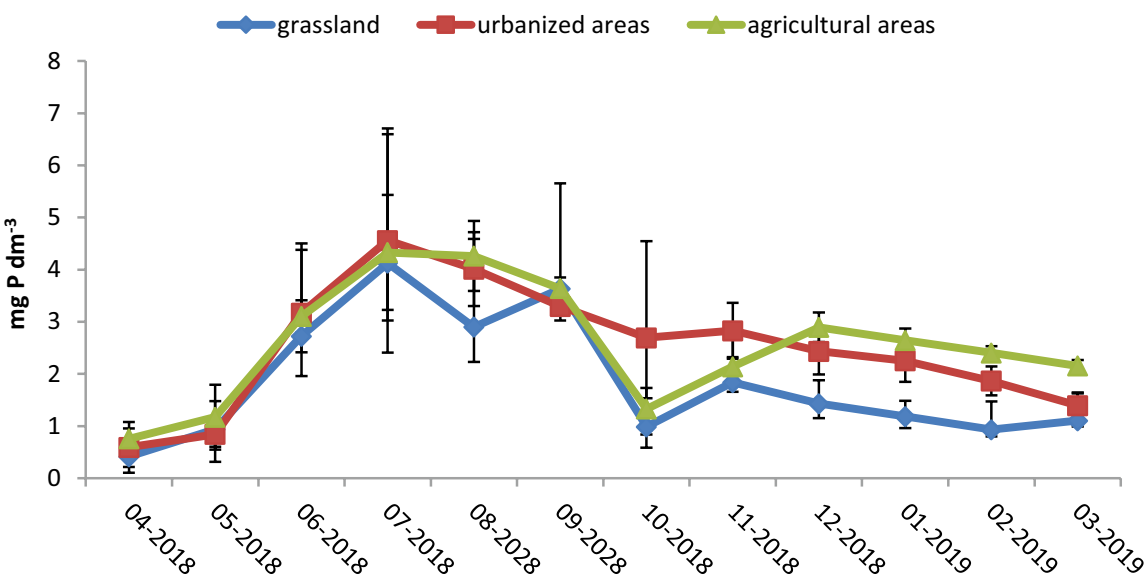

We tested the concentrations of total phosphorus with the use of the spectrophotometric method with ammonium molybdate (according to PN-EN ISO 6878: 200) and ammonium and nitrate nitrogen with the use of flow colorimetry (according to PN-EN ISO 11732: 2007)

The results were processed using the 1-factor ANOVA method with the $p$-value of significance below 0.05 (Table 1).

The measurement results were compared with the Polish Regulation of the Minister of Maritime Economy and Inland Navigation on 11 October (2019) on the classification of ecological condition, ecological potential, chemical condition, and the method of classification of the state of surface water bodies, as well as environmental quality standards for priority substances.

\section{Results}

The average concentration of total phosphorus in the waters of the Utrata River amounted to 2.15 $\mathrm{mg} \mathrm{P} / \mathrm{dm}^{3}$, significantly exceeding the permissible values for class I and II water quality (according to the Polish Regulation of the Minister of Maritime Economy and Inland Navigation), which are 0.17 and $0.33 \mathrm{mg} \mathrm{P} / \mathrm{dm}^{3}$, respectively. The lowest average concentration of total phosphorus in waters of the river was measured in spring on grasslands (sampling locations 1 to 8), and it amounted to an average of $0.78 \mathrm{mg} \mathrm{P} / \mathrm{dm}^{3}$, while the highest concentration of total phosphorus was observed in summer in agricultural and urbanized areas (with 3.9 and $3.91 \mathrm{mg} \mathrm{P} / \mathrm{dm}^{3}$ ).

The difference in average values of total phosphorus concentration in urbanized areas as compared to grasslands was $0.64 \mathrm{mg} \mathrm{P} / \mathrm{dm}^{3}$, while the average difference in concentration in agricultural areas compared to urbanized areas amounted to just $0.07 \mathrm{mg} \mathrm{P/}$ $\mathrm{dm}^{3}$.

The concentration of phosphorus gradually increased from the first measurement month (April) to July, when it reached the highest values, regardless of the type of
Fig. 6 Concentration of nitrate nitrogen in the Utrata River in the months of April 2018-March 2019

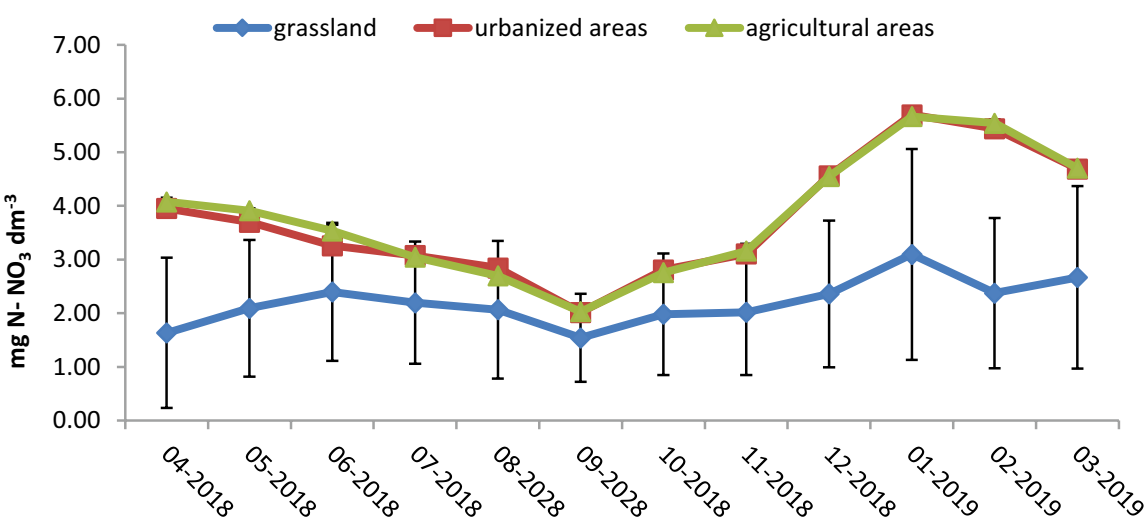


Table 1 Permissible values in the first and second water quality classes of total phosphorus and ammonium and nitrate nitrogen in Utrata River according to the Polish Regulation of the Minister of Maritime Economy and Inland Navigation

\begin{tabular}{|c|c|c|}
\hline Pollutants & Class & Values \\
\hline \multirow[t]{2}{*}{$\mathrm{N}-\mathrm{NO}_{3}\left(\mathrm{mg} / \mathrm{dm}^{3}\right)$} & I water quality class & 1.1 \\
\hline & II water quality class & 2.0 \\
\hline \multirow[t]{2}{*}{$\mathrm{N}-\mathrm{NH}_{4}\left(\mathrm{mg} / \mathrm{dm}^{3}\right)$} & I water quality class & 0.25 \\
\hline & II water quality class & 0.738 \\
\hline \multirow[t]{2}{*}{ Total P (mg/dm³) } & I water quality class & 0.17 \\
\hline & II water quality class & 0.33 \\
\hline
\end{tabular}

land use. In the summer period (June-September), the phosphorus concentrations remained at a very high level. In October, there was a sharp decrease in phosphorus concentration in grasslands and agricultural areas, while at the same time high values were still recorded in urbanized areas. Regardless of the land use, in the winter months (December-February), the concentrations of phosphorus dropped.

The average concentration of nitrate nitrogen was $3.06 \mathrm{mg} \mathrm{N}-\mathrm{NO}_{3} / \mathrm{dm}^{3}$, and it fell outside the range of class II water quality (according to the Polish Regulation of the Minister of Maritime Economy and Inland Navigation). Only in grasslands was the average concentration of nitrate nitrogen $\left(2.2 \mathrm{mg} \mathrm{N}-\mathrm{NO}_{3} / \mathrm{dm}^{3}\right)$ within the range for the class II water quality. The average concentration of nitrate nitrogen in urbanized areas was $3.76 \mathrm{mg} \mathrm{N}-\mathrm{NO}_{3} / \mathrm{dm}^{3}$, while in agricultural areas, it amounted to $3.81 \mathrm{mg} \mathrm{N}-\mathrm{NO}_{3} / \mathrm{dm}^{3}$; both of these values significantly exceed the permissible values for class I and II water quality, which are 1.1 and $2.0 \mathrm{mg} \mathrm{N}-\mathrm{NO}_{3} / \mathrm{dm}^{3}$, respectively (Table 2).

The lowest average concentration of nitrate nitrogen was recorded in autumn in grasslands and was $1.85 \mathrm{mg} \mathrm{N}-\mathrm{NO}_{3} / \mathrm{dm}^{3}$, while the highest average concentration was observed in winter in agricultural and urbanized areas (5.23 and $5.25 \mathrm{mg} \mathrm{N}-\mathrm{NO}_{3} / \mathrm{dm}^{3}$, respectively).

The average excess in nitrate nitrogen concentrations in urbanized areas as compared to grasslands was $1.56 \mathrm{mg} \mathrm{N}-\mathrm{NO}_{3} / \mathrm{dm}^{3}$, while its average excess in concentration in agricultural areas compared to urbanized areas amounted to $0.04 \mathrm{mg} \mathrm{N}-\mathrm{NO}_{3} / \mathrm{dm}^{3}$.

The average concentration of ammonium nitrogen in the Utrata River was $0.81 \mathrm{mg} \mathrm{N}-\mathrm{NH}_{4} / \mathrm{dm}^{3}$, and it exceeded the permissible threshold values for water quality classes I and II (according to the Polish
Regulation of the Minister of Maritime Economy and Inland Navigation). The average concentration of ammonium nitrogen was the lowest in grasslands, amounting to $0.51 \mathrm{mg} \mathrm{N}-\mathrm{NH}_{4} / \mathrm{dm}^{3}$ (the lowest observed averaged concentration was $0.27 \mathrm{mg}$ $\mathrm{N}-\mathrm{NH}_{4} / \mathrm{dm}^{3}$ and it was within the limits of the class II water quality).

The average concentration of ammonium nitrogen in urbanized and agricultural areas did not differ significantly and amounted to $1.07 \mathrm{mg} \mathrm{N}-\mathrm{NH}_{4} / \mathrm{dm}^{3}$ for the urbanized areas and $1.08 \mathrm{mg} \mathrm{N}-\mathrm{NH}_{4} / \mathrm{dm}^{3}$ for the agricultural ones. The highest average concentration of this form was recorded in summer in agricultural areas, where it amounted to $1.4 \mathrm{mg} \mathrm{N}-\mathrm{NH}_{4} / \mathrm{dm}^{3}$, significantly exceeding the permissible value for class II water quality $\left(0.4 \mathrm{mg} \mathrm{N}-\mathrm{NH}_{4} / \mathrm{dm}^{3}\right)$.

The average excess in ammonium nitrogen concentrations in urbanized areas as compared to grasslands was $0.56 \mathrm{mg} \mathrm{N}-\mathrm{NH}_{4} / \mathrm{dm}^{3}$, while its average excess in concentration in agricultural areas compared to urbanized areas amounted to $0.01 \mathrm{mg} \mathrm{N}-\mathrm{NH}_{4} / \mathrm{dm}^{3}$.

The concentration of ammonium nitrogen in grasslands was lower than that in urbanized and agricultural areas (with the average value in green areas of $0.51 \mathrm{mg} \mathrm{N}-\mathrm{NH}_{4} / \mathrm{dm}^{3}$ and averages in urbanized and agricultural areas of 1.07 and $1.08 \mathrm{mg} \mathrm{N}-\mathrm{NH}_{4} / \mathrm{dm}^{3}$, respectively); only for September did we record an abrupt shift in the concentration of ammonium nitrogen in green areas.

Statistical analysis proved a significant impact on the season and the way land was used on all analyzed indicators, but it failed to prove the influence of the water level or weather conditions.

Table 2 Statistical analysis (one-way ANOVA)

\begin{tabular}{llll}
\hline $\boldsymbol{Y}$ & $\boldsymbol{X}$ & $\boldsymbol{n}$ & $\boldsymbol{p}$-value \\
\hline $\mathrm{N}-\mathrm{NO}_{3}\left(\mathrm{mg} / \mathrm{dm}^{3}\right)$ & Land use & 252 & $2.1 \mathrm{E}-25$ \\
& Air temperature & 252 & $1.87 \mathrm{E}-16$ \\
& Season of the year & 252 & $9.5 \mathrm{E}-17$ \\
& Water level & 252 & $4.41 \mathrm{E}-11$ \\
$\mathrm{~N}-\mathrm{NH}_{4}\left(\mathrm{mg} / \mathrm{dm}^{3}\right)$ & Land use & 252 & $6.00 \mathrm{E}-37$ \\
& Season of the year & 252 & $1.9 \mathrm{E}-08$ \\
& Air temperature & 252 & $2.51 \mathrm{E}-08$ \\
& Water level & 252 & $3.30 \mathrm{E}-05$ \\
Total P $\left(\mathrm{mg} / \mathrm{dm}^{3}\right)$ & Land use & 252 & $1.5 \mathrm{E}-07$ \\
& Season of the year & 252 & $1.1 \mathrm{E}-23$ \\
& Air temperature & 252 & $9.93 \mathrm{E}-23$ \\
& Water level & 252 & $1.60 \mathrm{E}-18$ \\
\hline
\end{tabular}




\section{Discussion}

The cause behind increased phosphorus concentrations in rivers in urbanized areas can be runoffs from sewage treatment plants and storm drain systems, and it has been proven in many studies (Hu et al., 2019; Charlton et al., 2017). In October, we can observe higher concentrations of phosphorus in urbanized areas, as compared to agricultural and grassland areas, which may be related to the inflow to the Utrata from the highly polluted Raszynka River. Raszynka could deliver a significant load of phosphorus, which becomes diluted further downriver. The significant effect of the sewage treatment plants on the phosphorus concentrations in rivers was also observed by Yuan et al. (2019).

The increased inflow of total phosphorus in agricultural areas in summer is associated with rainfall washing away phosphorus fertilizers from the soil (Ryberg, 2017; Boardman et al., 2019), which, as the terrain drops, then gets into river valleys ( $\mathrm{Wu} \&$ $\mathrm{Lu}, 2019)$.

The concentration of nitrate ions in the waters of the Utrata River increased in the urbanized area, and this shift in concentration may be related to the discharge of water from the sewage treatment plants. On the other hand, the increase in the concentration of nitrate ions in agricultural areas may be related to leaching nitrogen fertilizers from the soil (Torma et al., 2019). The presence of nitrate ions in grasslands may indicate leaky septic tanks located in the catchment area (Górski et al., 2019). The highest concentrations of nitrate ions were recorded in winter, and Dolgov and Koronkevich (2019) also report that the greatest leaching of nitrate ions from agricultural areas occurs between December and February.

The high concentration of ammonium ions in the water of the Utrata River may indicate its severe pollution with commercial and industrial sewage (Agca \& Doğan, 2019). A large change in the concentration of ammonium ions in September in grasslands may be associated with a one-time pollution from a single source, e.g., discharge of sewage straight into the river, and these pollutants were diluted further downstream.

A large change in the concentration of biogenic substances is related to the presence of a sewage treatment plant, the discharge of which ends up in the waters of the Utrata River (sampling locations
5 and 6). Even properly operating sewage treatment plants fail to remove $100 \%$ of the biogenic pollutants (Bawiec, 2018).

Wastewater treatment plants located in the vicinity of the Utrata River significantly affect its flow and chemical condition. Research proves that for over 50 years, the growing urbanization of areas (and the resulting fragmentation of the area), human activity, and climate change have significantly influenced the chemical condition of the water in the upper and middle courses of the Utrata River (Somorowska \& Łaszewski, 2019).

A large inflow of pollutants may also be attributed to the unused fish ponds upstream of Walendow, which is probably caused by very substantial contamination of the ponds with biogenic substances that get into the river from the bottom sediments. On the other hand, the increase in the concentration of pollutants in location no. 9 could have occurred as a result of the presence of fish ponds in Pęcice and the influx of pollutants from the Raszynka River to the researched Utrata River. Kieu et al. (2020) also observed a high content of phosphorus and nitrogen forms in fish ponds.

Raszynka is a river with low water quality, and research carried out by Burzyńska published in (2019) demonstrated high concentrations of nitrogen and phosphorus in its waters. The waters of the Raszynka River were the most polluted in its lower course at the mouth, which may explain the increase in nutrient concentration in Utrata (sampling location 9). A 2015 research also confirmed high levels of pollution in the Raszynka River (Burzyńska, 2016).

The high concentration of nitrate ions, ammonium ions, and total phosphorus in combination with the high temperature of that river (Łaszewski, 2016) and the progressive urbanization may have led to the eutrophication process, which can be observed more and more often in river waters (Hutchins \& Hitt, 2019).

The analysis carried out on the river measurement results failed to prove a statistically significant influence of water levels or air temperature on the concentration of biogenic substances in Utrata (Fig. 7). The negative effect of high air temperature on the overall water quality of rivers was proven by Ozaki et al. (2003), but the effect is limited to changes in concentrations of dissolved oxygen, COD, and water temperature. No data would seem to indicate an effect of air temperature on the concentration of biogenic substances in rivers. 
Fig. 7 Concentration of ammonium nitrogen in the Utrata River in the months of April 2018-March 2019

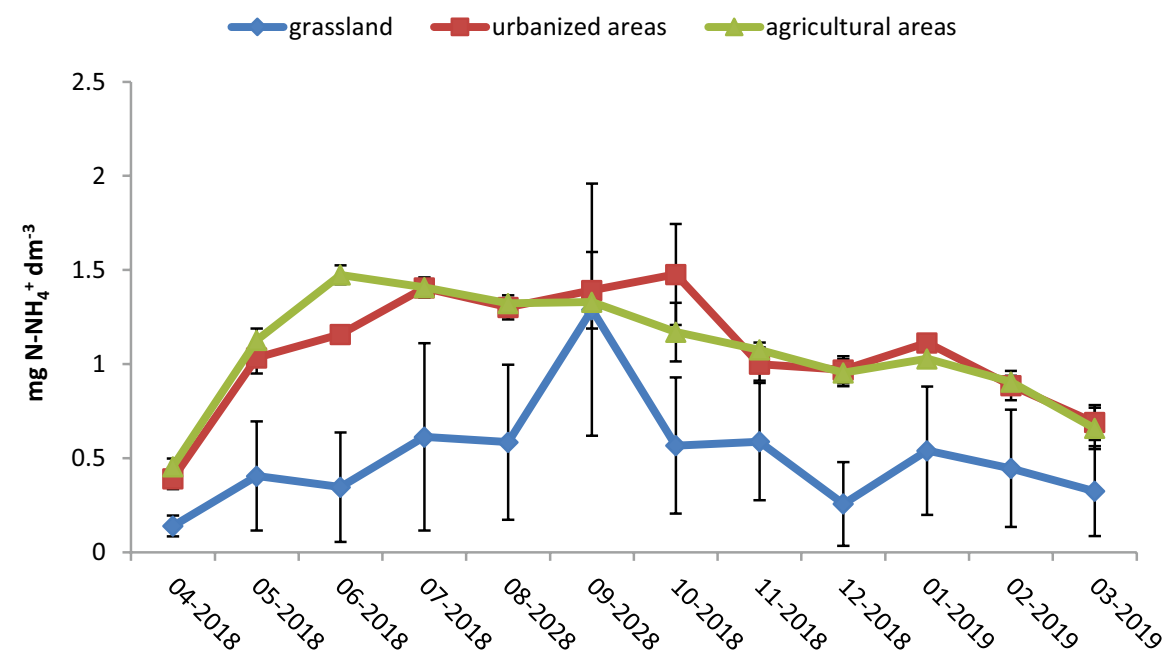

\section{Conclusion}

The waters of the Utrata River were of poor quality owing to the high concentration of ammonium ions, nitrate ions, and total phosphorus. The most polluted part of the river was its lower course, which was dominated by agricultural land development; the least polluted were the waters from the upper part of the river, where wastelands, forests, and low levels of urbanization prevailed.

The Utrata River is polluted with nitrate and ammonium nitrogen in urbanized and agricultural areas.

We recorded a strong correlation between the concentration of the tested biogenic substances and the season of the year, and at the same time, no influence of air temperature and water level on the pollution.

\section{Declarations}

Ethics approval Not applicable.

Consent to participate Not applicable.

\section{Consent for publication Not applicable.}

Conflict of interest The authors declare no competing interests.
Open Access This article is licensed under a Creative Commons Attribution 4.0 International License, which permits use, sharing, adaptation, distribution and reproduction in any medium or format, as long as you give appropriate credit to the original author(s) and the source, provide a link to the Creative Commons licence, and indicate if changes were made. The images or other third party material in this article are included in the article's Creative Commons licence, unless indicated otherwise in a credit line to the material. If material is not included in the article's Creative Commons licence and your intended use is not permitted by statutory regulation or exceeds the permitted use, you will need to obtain permission directly from the copyright holder. To view a copy of this licence, visit http://creativecommons.org/licenses/by/4.0/.

\section{References}

Ağca N., \& Doğan K. (2019). Assessment of ammonium, nitrate and phosphorus pollution in the Asi River. 1st International Congress on Biosystems Engineering (ICOBEN2019) 24-27 September 2019, Antakya, Hatay, Turkey

Armstrong, B. M., Lazorchak, J. M., Murphy, C. A., Haring, H. J., Jensen, K. M., \& Smith, M. E. (2012). Determining the effects of ammonia on fathead minnow (Pimephales promelas) reproduction. Science of The Total Environment, 420, e127-e133. https://doi.org/10.1016/j.scitotenv. 2012.01.005

Baker, A. (2006). Land use and water quality. Encyclopedia of hydrological sciences. Edited by M. Anderson. 2005 John Wiley \& Sons, Ltd. https://doi.org/10.1002/0470848944. hsa195

Bartnicki, J. (2019). Atmospheric contribution to eutrophication of the Baltic Sea. Air Pollution Modeling and its Application XXVI, pp 53-57. https://doi.org/10.1007/ 978-3-030-22055-6_9

Bawiec, A. (2018). Efficiency of nitrogen and phosphorus compounds removal in hydroponic wastewater treatment 
plant. Environmental Technology. https://doi.org/10. 1080/09593330.2018.1436595

Boardman, E., Danesh-Yazdi, M., Foufoula-Georgiou, E., Dolph, C. L., \& Finlay, J. C. (2019). Fertilizer, landscape features and climate regulate phosphorus retention and river export in diverse Midwestern watersheds. Biogeochemistry, 146, 293-309. https://doi.org/10.1007/ s10533-019-00623-z

Burzyńska, I. (2016). Ocena wybranych wskaźników fizykochemicznych w wodach rzeki raszynki. WaterEnvironment-Rural Areas (VII-IX). T. 16. Z, 3(55) ISSN $1642-8145$ s. $23-34$

Burzyńska, I. (2019). Monitoring of selected fertilizer nutrients in surface waters and soils of agricultural land in the river valley in Central Poland. Journal Of Water And Land Development, ISSN 1429-7426, e-ISSN 20834535. https://doi.org/10.2478/jwld-2019-0061

Cavalcante, H., Cruz, P. S., Viana, L. G., Silva, D. D. L., \& Barbosa, J. E. D. L. (2017). Influence of the use and the land cover of the catchment in the water quality of the semiarid tropical reservoirs. Journal of Hyperspectral Remote Sensing, 7, 389-398, ISSN:2237-2202.

Charlton, M. B., Bowes, M. J., Hutchins, M. G., Orr, H. G., Soley, R., \& Davison, P. (2017). Mapping eutrophication risk from climate change: Future phosphorus concentrations in English rivers. Science of the Total Environment, 593-594, 688-694. https://doi.org/10.1016/j.scitotenv. 2017.03.136

Dolgov, S. V., \& Koronkevich, N. I. (2019). Biogenic runoff from the Nizhny Novgorod Area, hydrochemical and hydrobiological processes: Environmental aspects. Water Resources, 46, S94-S100. https://doi.org/10.1134/ S0097807819070054

Dzhamalov, R. G., Kosolapov, A. E., Vlasov, K. G., Myagkova, K. G., Reshetnyak, O. S., \& Safronova, T. I. (2019). Pollution degree of the Don River water. Water Resources And The Regime Of Water Bodies. https://doi.org/10.1134/ S0097807819070066

Fierro, P., Bertrán, C., Tapia, J., Hauenstein, E., Peña-Cortés, F., Vergara, C., Cerna, C., \& Vargas-Chacoff, L. (2017). Effects of local land-use on riparian vegetation, water quality, and the functional organization of macroinvertebrate assemblages. Science of The Total Environment, 609, 724734. https://doi.org/10.1016/j.scitotenv.2017.07.197

Górski, J., Dragon, K., \& Kaczmarek, P. (2019). Nitrate pollution in the Warta river (Poland) between 1958 and 2016: Trends and causes. 2017 Environmental Science and Pollution Research, 26, 2038-2046. https://doi.org/10.1007/ s11356-017-9798-3

Hampel, J. J., McCarthy, M. J., Gardner, W. S., Zhang, L., Xu, H., Zhu, G., \& Newell, S. E. (2017). Nitrification and ammonium dynamics in Taihu Lake, China: Seasonal competition for ammonium between nitrifiers and cyanobacteria. Biogeosciences, 15(2018), 733-748. https://doi.org/ 10.5194/bg-15-733-2018 https://dane.imgw.pl/data/dane_ pomiarowo_obserwacyjne/ - access 14 Aug $2020 \mathrm{https}: / /$ mapy.geoportal.gov.pl/imap/Imgp_2.html?gpmap=gp0 access 06 Feb 2020 https://www.google.pl/maps/@52. $0917827,20.757677,10 \mathrm{z} / \mathrm{data}=! 5 \mathrm{~m} 1$ !1e4 - access 11 Mar 2021
Hu, Y., Long, C., Wang, Y., Kerkez, B., \& Scavia, D. (2019). Urban total phosphorus loads to the St. Clair-Detroit river system. Journal of Great Lakes Research. https:// doi.org/10.1016/j.jglr.2019.09.009

Hutchins, M. G., \& Hitt, O. E. (2019). Sensitivity of river eutrophication to multiple stressors illustrated using graphical summaries of physics-based river water quality model simulations. Journal of Hydrology, 577, 123917. https://doi.org/10.1016/j.jhydrol.2019.123917

Kieu, L. D., Nguyen, P. Q., Brix, H., \& Trang, N. T. D. (2020). Phytoremediation potential of Hymenachne acutigluma in removal of nitrogen and phosphorus from catfish pond water. Journal of Environmental Treatment Techniques, 8(1), 448-454.

Łaszewski, M. (2016). Relationships between environmental metrics and water temperature: A case study of Polish lowland rivers. Water and Environment Journal, Print ISSN 1747-6585. https://doi.org/10.1111/wej.12173

Lúcia, R., Nobre, G., Caliman, A., Rodrigues Cabral, C., Araújo, F. D. C., Guérin, J., Catombé Dantas, F. D. C., Quesado, L. B., Venticinque, E. M., Guariento, R. D., Amado A. M., Kelly, P., Vanni, M. J., \& Carneiro, L.S. (2020). Precipitation, landscape properties and land use interactively affect water quality of tropical freshwaters. Science of The Total Environment, 716, 137044, ISSN 0048-9697. https://doi. org/10.1016/j.scitotenv.2020.137044

Mingming, H., Yuchun, W., Pengcheng, D., Yong, S., Aiminc, C., Cong, L., Yufei, B., Yanhui, L., Shanze, L., \& Panwei, Z. (2019). Tracing the sources of nitrate in the rivers and lakes of the southern areas of the Tibetan Plateau using dual nitrate isotopes. Science of the Total Environment, 658, 132-140. https://doi.org/10.1016/j.scitotenv.2018. 12.149

Ozaki, N., Fukushima, T., Harasawa, H., Kojiri, T., Kawashima, K., \& Ono, M. (2003). Statistical analyses on the effects of air temperature fluctuations on river water qualities. Hydrological Processes, 17, 28372853.https://doi.org/10.1002/hyp.1437, https://doi.org/ 10.1002/hyp. 1437

Paule-Mercado, M., Lee, B., Memon, S., Umer, S., Salim, I., \& Lee, C. H. (2017). Influence of land development on stormwater runoff from a mixed land use and land cover catchment. Science of the Total Environment, 599, 2142-2155.

Regulation of the Minister of Maritime Economy and Inland Navigation. (2019). On the classification of ecological condition, ecological potential, chemical condition, and the method of classification of the state of surface water bodies, as well as environmental quality standards for priority substances.

Rodrigues, V., Estrany, J., Ran-zini, M., de Cicco, V., Tarjuelo Martín-Benito, J. M., Hedo, J., \& Lucas-Borja, M. E. (2018). Effects of land use and seasonality on stream water quality in a small tropical catchment: The headwater of Córrego Água Limpa, São Paulo (Brazil). Science of the Total Environment, 622, 1553-1561.

Ryberg, K. R. (2017). Structural equation model of total phosphorus loads in the Red River of the North Basin, USA and Canada. Journal of Environmental Quality s, 2017, 1072-1080. https://doi.org/10.2134/jeq2017.04.0131

Rydałowski, M., Jurczuk, S., \& Łempicka, A. (2008). Charakterystyka sprzętu i organizacji użytkowania 
środków ochrony roślin w gospodarstwach na terenie Utraty. Water-Environment-Rural Areas t. 8 z, 2a(23), 63-79.

Schmalz, B., \& Kruse, M. (2019). Impact of land use on stream water quality in the German low mountain range Basin Gersprenz. Landscape Online, 72, 1-17. https://doi.org/ 10.3097/LO.201972

Shen, Z., Li, Z., \& Miao, H. (2020). Budget and control of phosphorus in the Changjiang River catchment and its mouth. 2020 Studies of the Biogeochemistry of Typical Estuaries and Bays in China, 61-80. https://doi.org/10. 1007/978-3-662-58169-8_4

Shi, P., Zhang, Y., Song, J., Li, P., Wang, Y., Zhang, X., Li, Z., Bi, Z., Zhang, X., Qin, Y., \& Zhu, T. (2019). Response of nitrogen pollution in surface water to land use and socialeconomic factors in the Weihe River watershed, northwest China. Sustainable Cities and Society, 50, 101658, ISSN 2210-6707. https://doi.org/10.1016/j.scs.2019.101658

Somorowska, U., \& Łaszewski, M. (2019). Quantifying streamflow response to climate variability, wastewater inflow, and sprawling urbanization in a heavily modified river basin. Science of The Total Environment, 656, 458-467. https://doi.org/10.1016/j.scitotenv.2018.11.331

Torma, S., Koco, Š., Vilček, J., \& Čermák, P. (2019). Nitrogen and phosphorus transport in the soil from the point of view of water pollution. Folia Geographica, 61(1), 143156. ISSN 1336-6157.
Wang, S., Lu, A., Dang, S., \& Chen, F. (2016). Ammonium nitrogen concentration in the Weihe River, central China during 2005-2015. Environmental Earth Sciences, 75(6). https://doi.org/10.1007/s12665-015-5224-7

Wojtkowska, M. (2006). Wpływ sposobu zagospodarowania zlewni na poziom zanieczyszczenia rzeki Utraty. Gaz, Woda i Technika Sanitarna Nr, 11, 70-72.

Wu, J., \& Lu, J. (2019). Landscape patterns regulate non-point source nutrient pollution in an agricultural watershed. Science of The Total Environment, 669, 377-388. https://doi. org/10.1016/j.scitotenv.2019.03.014

Yuan, S., Tang., Xiao, Y., Xia, Y., Melching, C., \& Li, Z. (2019). Phosphorus contamination of the surface sediment at a river confluence. Journal of Hydrology, 573, 568580. https://doi.org/10.1016/j.jhydrol.2019.02.036

Zwolsman, J. J. G., \& van Bokhoven, A. J. (2007). Impact of summer droughts on water quality of the Rhine River - A preview of climate change?. Water Science \& Technology, 56(4), 45-55. https://doi.org/10.2166/wst.2007.535

Publisher's Note Springer Nature remains neutral with regard to jurisdictional claims in published maps and institutional affiliations. 